\title{
MINERAL WEATHERING IN ACID SAPROLITES FROM SUBTROPICAL, SOUTHERN BRAZIL
}

\author{
Celso Augusto Clemente*; Antonio Carlos de Azevedo \\ USP/ESALQ - Depto. de Ciência do Solo - C.P. 09 - 13418-900 - Piracicaba, SP - Brasil. \\ *Corresponding author <clemente@esalq.usp.br>
}

\begin{abstract}
Because weathering of minerals releases chemical elements into the biogeochemical cycle, characterization of their weathering products helps to better model groundwater quality, formation of secondary minerals and nutrient flux through the trophic chain. Based on microscopic and elemental analyses, weathering of riodacite from Serra Geral formation was characterized and weathering paths proposed. Three weathering paths of plagioclase phenocrystals were identified: plagioclase to gibbsite (Pg1); plagioclase to gels and gibbsite (Pg2); and plagioclase to gels, gibbsite and kaolinite (Pg3). Pyroxenes weathered to smectite and goethite (Py1), or to goethite and gibbsite (Py2), and magnetite weathered directly into iron oxides. Rock matrix comprises $90 \%$ of rock volume, and weathered to kaolinite and gibbsite, which explains why these minerals were the most abundant in the weathering products of these saprolites.

Key words: Paraná Basin, riodacites, plagioclases, pyroxenes, magnetites
\end{abstract}

\section{INTEMPERISMO SUBTROPICAL DE MINERAIS EM SAPROLITOS ÁCIDOS DO SUL DO BRASIL}

\begin{abstract}
RESUMO: O intemperismo de minerais primários disponibiliza elementos químicos no ciclo biogeoquímico, que por sua vez influencia a qualidade da água subterrânea, formação de minerais secundários e o fluxo de nutrientes na cadeia trófica. Com base na análise microscópica e elemental, o intemperismo de riodacito da formação Serra Geral foi caracterizado e mecanismos de intemperismo propostos. Três processos principais de intemperismo de fenocristais de plagioclásios foram identificados: plagioclásio para gibbsita (Pg1); plagioclásio para gel e gibbsita (Pg2), e plagioclásio para gel, gibbsita e caulinita (Pg3). Piroxênios intemperizaram-se para esmectita e goetita (Py1), ou para goethita e gibbsita (Py2), e magnetita intemperizou-se para óxidos de ferro. A matriz da rocha compõe $90 \%$ do volume total, e intemperiza-se para caulinita e gibbsita, o que explica a abundância destes minerais nos produtos de intemperismo destes saprolitos.

Palavras-chave: Bacia do Paraná, riodacitos, pagioclasios, piroxênios, magnetitas
\end{abstract}

\section{INTRODUCTION}

Weathering is a key process that releases chemical elements into de biogeochemical cycle so they become acessible to living organisms in the trophic chain, leach to groundwater, or precipitate as a new, secondary mineral phase (Hutchinson, 1970). These secondary phases are, as a rule, very reactive and strongly related to the adsorptive behavior of the regolith column.

One million square kilometers of the lava flows of Serra Geral Formation (SGF) consists of basic rocks (Jurassic-Cretaceous age) while the acid members occupy the remaining 150,000 square kilometers (Roisenberg \& Viero, 2000). Due to their large extension and economical importance, the majority of geological and pedological research focussed on the basic rocks (Picirillo \& Melfi, 1988). Besides, until de 1980's, acid rocks were not mapped on SGF (Clemente, 1988).
The lava flows at the top of the plateaus of the Paraná Basin are acidic and the colder and wetter subtropical climate is a peculiar weathering environment as compared to the dominant tropical humid Brazil (Melfi \& Pedro, 1977; Melfi \& Pedro, 1978). Acid rocks in the SGF are classified as Palmas type (ATP) or Chapeco type (ATC) (Nardy, 1986). The ATC rocks are porfiritic (5 to $10 \%$ volume) with phenocrystals of plagioclase, augite, pigeonite and Ti-magnetite, while rock matrix has an intergrowth of quartz and alkaline feldspars, plagioclase, pyroxenes, Ti-magnetite, ilmenite and apatite (Sartori et al., 1973).

The objective of this work was to investigate and describe the most common weathering products of ATC type of acid rocks at the Palmas and Guarapuava plateaus (Paraná State) and to suggest weathering paths that produced them. 


\section{MATERIAL AND METHODS}

Samples were collected in seven regolith profiles along two topossequences ("Entre-Rios" and "Pinhão", Figure 1). Undisturbed samples were collected in metallic frames $14 \times 9 \times 8 \mathrm{~cm}$, dried at 45 $50^{\circ} \mathrm{C}$ by 24 hours and resin impregnated under vacuum according to Hanrion (1976). Each sample were sliced into 5 pieces, resulting in 500 slices approximately 6 $\mathrm{cm}$ thick. All pieces were observed under light microscope aiming to select the 140 more representative of the weathering features, and mounted on glass slides. Slide analyses were done under petrographic (light) microscope and Scanning Eletron Microscope (SEM). Microprobe was used to provide X-ray diffration (XRD) and elemental analyses of specific slide features.

According to main weathering features, saprolite layers were labeled from S1 downward to S4 (the deepest).

\section{RESULTS AND DISCUSSION}

Average thickness of saprolites was $3 \mathrm{~m}$, with a maximum of $7 \mathrm{~m}$. In the $\mathrm{S} 1$ layer, rock texture and structure were not recognized. A few yellowish spots in the reddish clayey matrix denoted remains of weathered rock fragments. Layers S1 were found from 0.6 to $3.0 \mathrm{~m}$ depth with thickness varying from 0.05 to $0.6 \mathrm{~m}$. Soil (solum) thickness above S1 layers ranged from 0.6 to $3.0 \mathrm{~m}$. In $\mathrm{S} 2$ the rock texture was not identified and rock structure was only distinguished by the bedding orientation and fracture pattern. A ferruginous clay matrix, redder and more cohesive than S3, was observed. Plagioclase phenocrystals clearly showed weathering features such as color change, and pyroxene and magnetite crystals had reddish rings that diffuse towards the matrix. These layers were found at depths varying from 0.95 to $3.0 \mathrm{~m}$ and with thickness from 0.25 to $1.9 \mathrm{~m}$. In S3, nuclei of preserved rock were the only spots where the rock texture and structure could be observed. The weathering features observed in the phenocrystals at S2 layer were less extensive. The saprolite matrix was yellow and more friable than in the S4 layer. The S3 layers were found at depths from 0.7 to $3.0 \mathrm{~m}$ ranging in thickness from 0.15 to $2.5 \mathrm{~m}$. The petrographic texture and structure of the bedrock were unaltered in the S4 layers. At the fracture zones a color gradient from gray (unweathered rock) to yellow was found. These layers were found at depths varying from 0.9 to $4.1 \mathrm{~m}$ and thickness from 0.8 to $2.5 \mathrm{~m}$.

The weathering paths and products observed in the phenocrystals are related to microfeatures (such as fissures and open surfaces) were leaching rates may vary in intensity. The microenvironments that appeared more intensely weathered were associated to large and connected pores formed by physical weathering and dissolution of large (pheno)crystals which were more effective in leaching the weathered soluble products (Schirrmeister \& Storr, 1994). Three weathering paths of plagioclase phenocrystals (Pg1, Pg2 and Pg3, Table 1) were indentifyed.

In Pg1 several fissures developed in a network in which an isotropic material was surrounded by "islands" of unweathered plagioclase. XRD analyses showed gibbsite diagnostic peaks. A microprobe transect along one of these features resulted in large $\mathrm{Si}, \mathrm{Al}$, and $\mathrm{Ca}$ contents in the plagioclase and high $\mathrm{Al}$

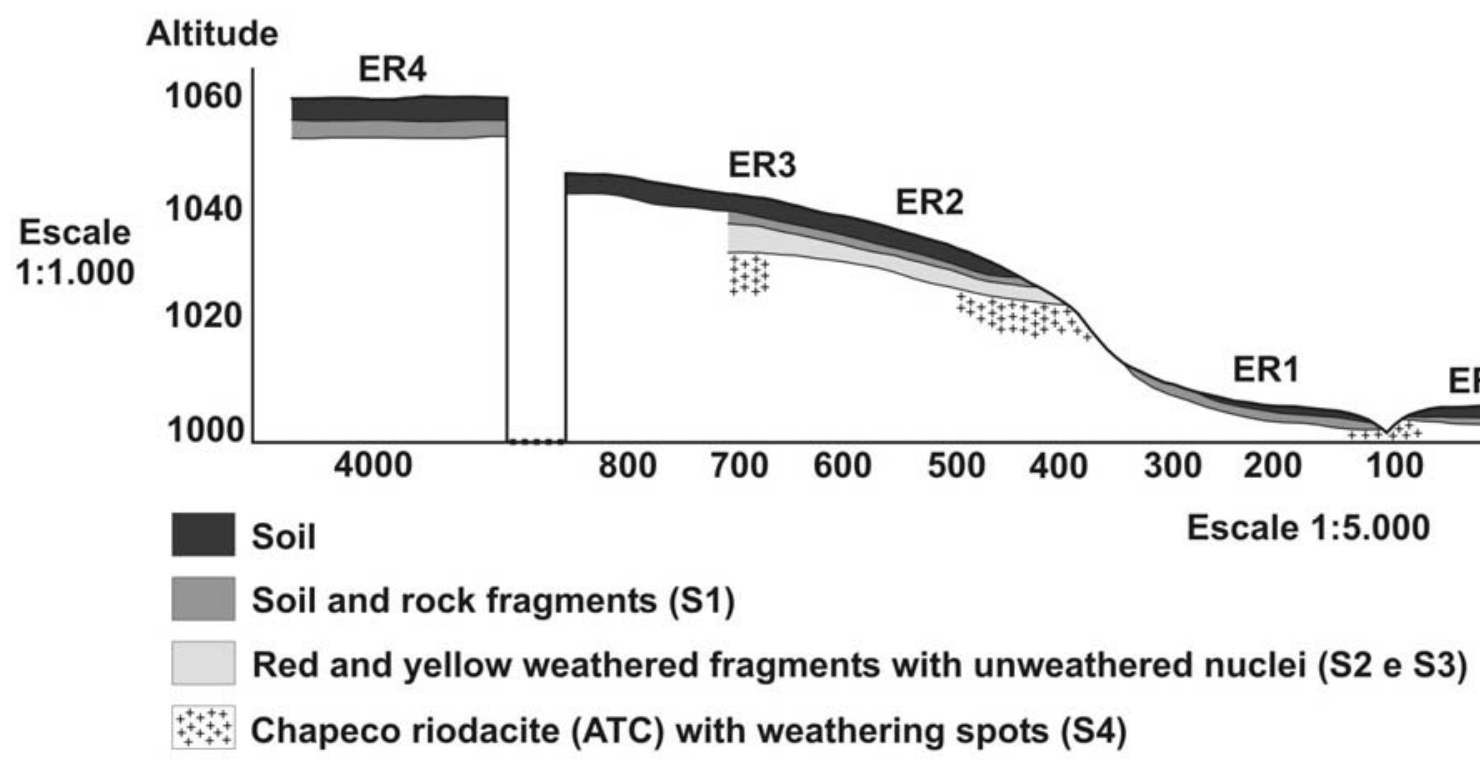

Figure 1 - Soil and Saprolite layers in Entre-Rios Toposequence. 
Table 1 - Primary minerals and weathering products of ATC acid rocks in the Palmas and Guarapuava plateaus.

\begin{tabular}{lcc}
\hline \multirow{2}{*}{ Mineral } & & Weathering \\
\cline { 2 - 3 } Plagioclase phenocrystal & path(s) & Products \\
\cline { 2 - 3 } & Pg1 & Gibbsite. \\
\hline Pyroxene & Pg2 & Gibbsite; Amorphous gel. \\
& Pg3 & Phollosilicate 2:1; Goethite. \\
\hline Magnetite and Ti-magnetite & Py1 & Gibbsite; Goethite. \\
\hline Rock matrix & Py2 & Hematite; Goethite. \\
\hline
\end{tabular}

concentration in the isotropic material (Figure 2). In addition, gibbsite crystals a few micrometers large were observed in the SEM images from fissures (Figure 5, feature 2). Therefore, gibbsite was the sole weathering product of Pg1. Many authors report similar weathering of feldspars directly to gibbsite (Delvigne, 1965; Boulange, 1984; Hsu, 1989; Huang, 1989; Certini et al., 2006; Chorover et al., 2004; Chandran et al., 2005).

In the Pg2 path plagioclase weathered to amorphous gel plus gibbsite. This path was found to be the most commom in all the studied samples. A typical feature was wide fissures filled with a gray to white (under polarized light) material, with undulating extinction and a refraction index smaller than the one from the plagioclase. In some of them, the material was slightly yellowed by the iron hidroxides released from the weathering of adjacent grains of magnetites and pyroxenes. In the fissures the material had a high $\mathrm{Al}$ concentration but there was an enrichment of $\mathrm{Fe}$ and mostly of Si along their axis (Figure 3). Since plagioclase have no $\mathrm{Fe}$, the axis of the fissure was probably a preferential leaching passageway. Such mechanism is common in crystalline rocks saprolites (Velbel, 1990).

The Pg3 path of weathering showed weathering of plagioclase to gels, kaolinite and gibbsite. This is typical in leaching less accesible microenvironments, such as narrow fissures (Figure 4, A) and concentric structures with "ladder steps" morphology. The fissure axis and its portion of contact with the mineral had similar amount of $\mathrm{Al}$, intermediate of $\mathrm{Si}$ and traces of $\mathrm{Fe}$ and P. However, two different morphologies for this material were observed in SEM images (Figure 4, B). In the same area, at the septa delimited by the fissures, the high resolution mode of SEM showed crystals of varied morphology while half way between the fissure and the core of the septum roughly hexagonal shaped crystals, with 5 micrometers diameter (Figure 4, C) have almost equal amounts of $\mathrm{Si}$ and $\mathrm{Al}$. At the core of the septum some hexagonal crystals with 0.5 micrometers

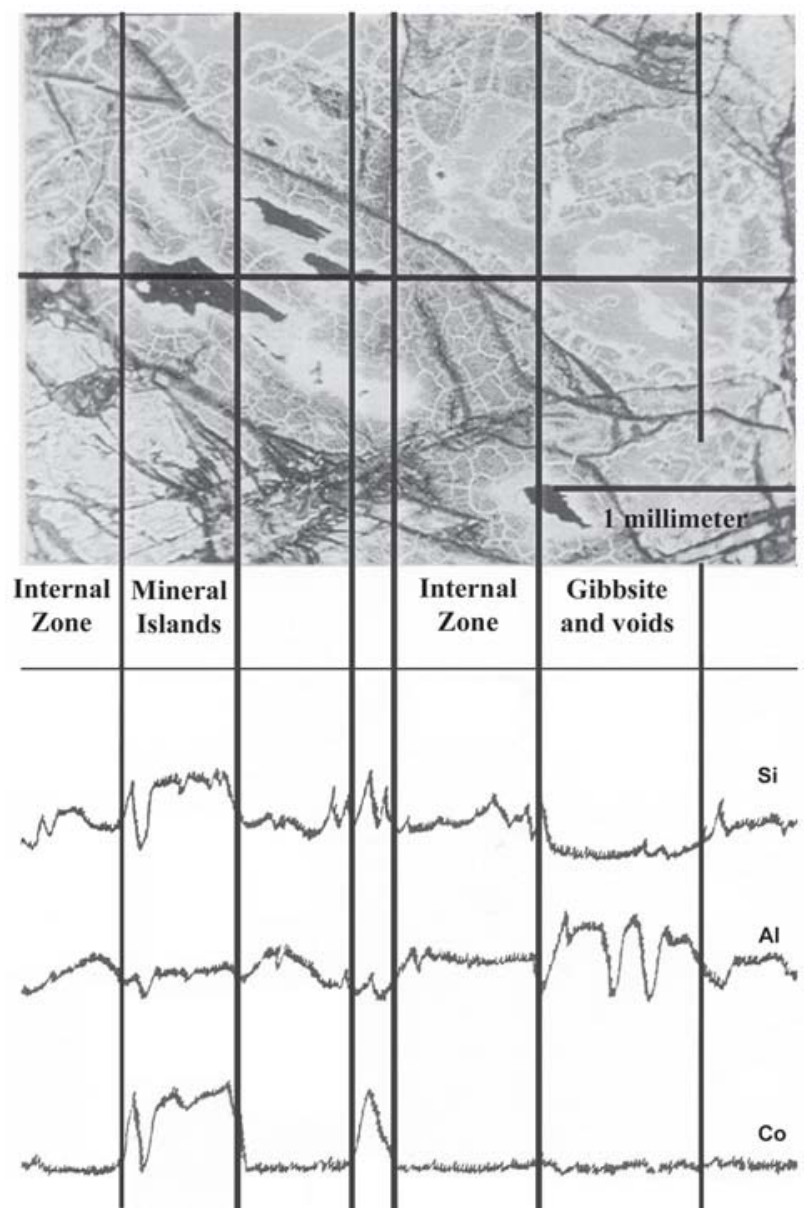

Figure 2 - Relative amount of $\mathrm{Si}, \mathrm{Al}$ and Ca along a transect a few millimeters long, on a weathered plagioclase crystal.

in diameter co-existed with elongated, prism-shaped crystals up to 5 micrometers long. Elemental analysis of the elongated crystals resulted in high amounts of Si and $\mathrm{Al}$ (Figure 5, top) probably kaolinite or a kaolinite/ 2:1 interestratified mineral, while the small crystals have mainly $\mathrm{Al}$ in their composition (Figure 5, bottom), suggesting to be gibbsite. Therefore, it seemed that in these narrow fissures a complex mixture of gels with varying composition co-existed with neoformed kaolinite and gibbsite. 


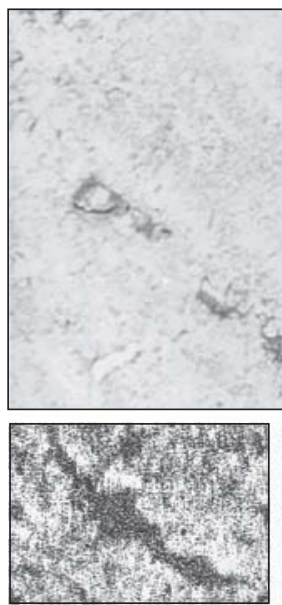

Al

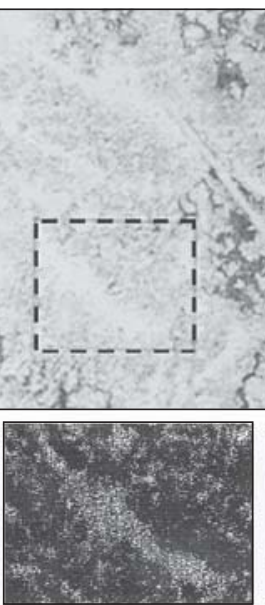

$\mathrm{Si}$
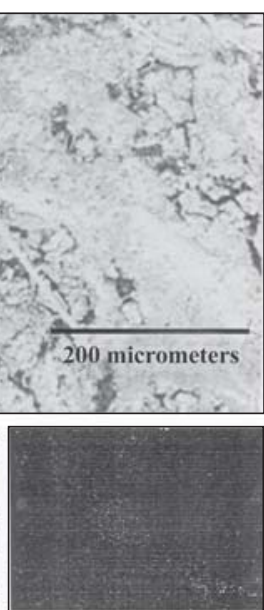

$\mathrm{Fe}$
Figure 3 - Elemental maps of $\mathrm{Al}, \mathrm{Si}$ and Fe from the analysed area in the above image (white dots mean presence of the respective element).

Weathering of pyroxenes started in the crystal grains from the fissures. On the Py1 path and at the broken planes the surfaces developed a light yellow color (as observed under polarized light). Formation of an incipient 2:1 silicate mineral was probably in course at these areas since microprobe results showed approximately two times more $\mathrm{Si}$ than $\mathrm{Al}$ and $\mathrm{Fe}$, which is in agreement with previous reports on weathering of pyroxenes in Brazil (Nahon, 1991). The large fissures were filled with an yellowish red material due to Fe oxide formation. Preserved crystal nuclei became less frequent and smaller from S4 to S2, and disappeared at S1. The small grain size of pyroxene crystals obstructed the use of XRD to identify 1:1-2:1 interstratified minerals, frequently associated to the weathering products of this mineral (Corrêa, 2003).

The Py2 path resulted in boxworks with suborthogonal morphology and rich in gibbsite and goethite (Figure 6). Boxwork is a morphologic feature formed during weathering of crystal grains in which the weathering products of small solubility (secondary clay, oxides and amorphous materials) are deposited in the breaking planes of the grain were they solidify. When the crystal grain is completely dissolved the small solubility products retain the morphology of the fissure network, and the empty volume in the network resembles the original volume of the crystal grain (Velbel, 1990). Formation of boxworks is a mechanism that maintain rock volume unchanged while weathering, which is a feature that distinguishes saprolite from soil (Gardner, 1992).

Magnetite and Ti-magnetite grains averaged one to two millimeters, some reaching eight millimeters and as large as the plagioclase grains, varying in amounts from 65 to $70 \%$ Fe and 12 to $24 \% \mathrm{Ti}$, respectively Con-

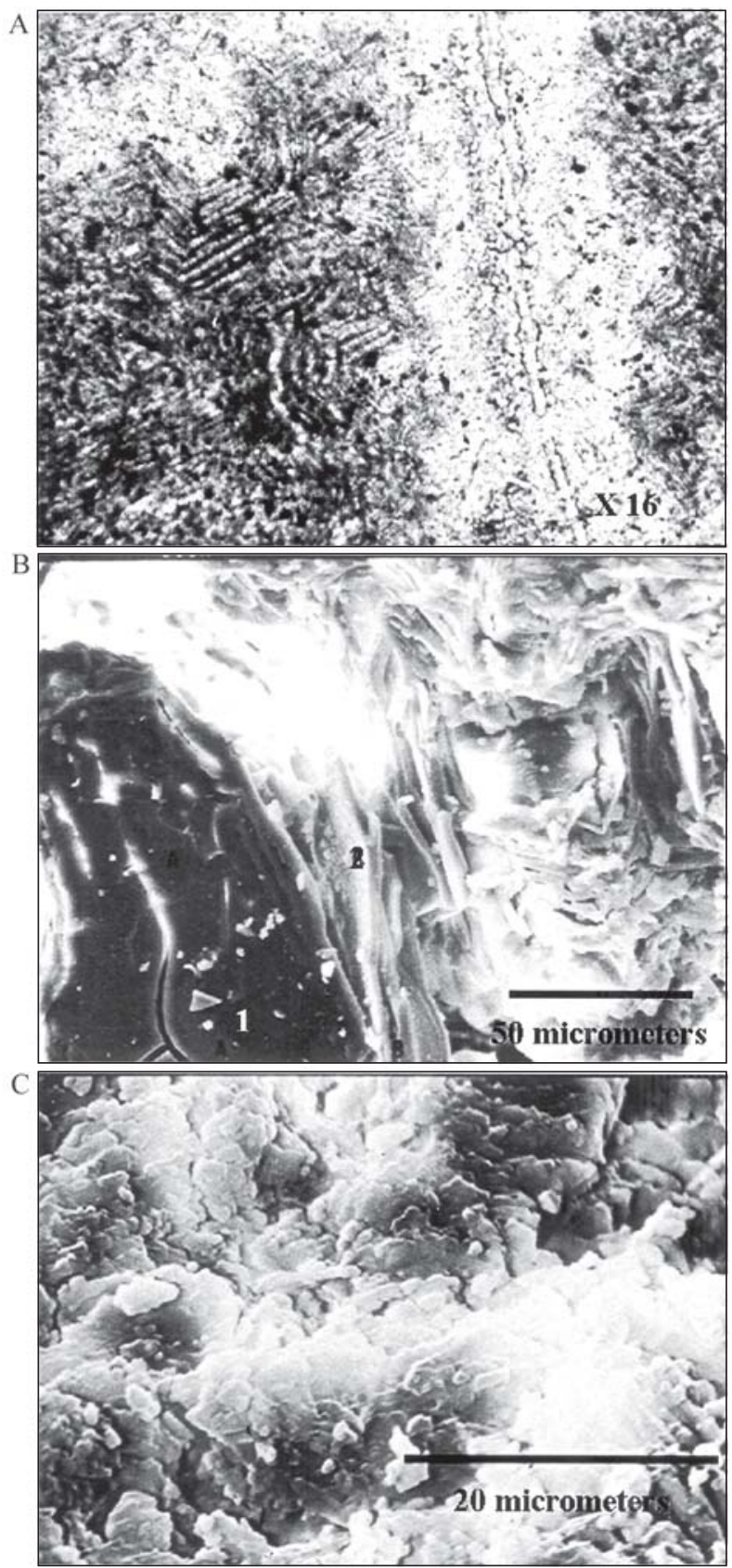

Figure 4 - Plagioclase weathering features: A) "Ladder steps" morphology; B) Two phases (1 and 2) with same chemical composition; C) Crystal morphology at a septum wall.

trasting to the fissure pattern of plagioclase and pyroxene grains, magnetite grains weathered from the external surfaces inwards. The weathering rings were dark red at the core turning into yellow outwards with up to $50 \%$ of Fe. The main products for magnetite weathering were goethite and hematite. It seemed that the high supply of $\mathrm{Fe}$ required to hematite synthesis (Schwertmann, 1985; Schwertmann \& Taylor, 1989) were reached at the core while Fe diffusion at the external rings favored goethite formation. 

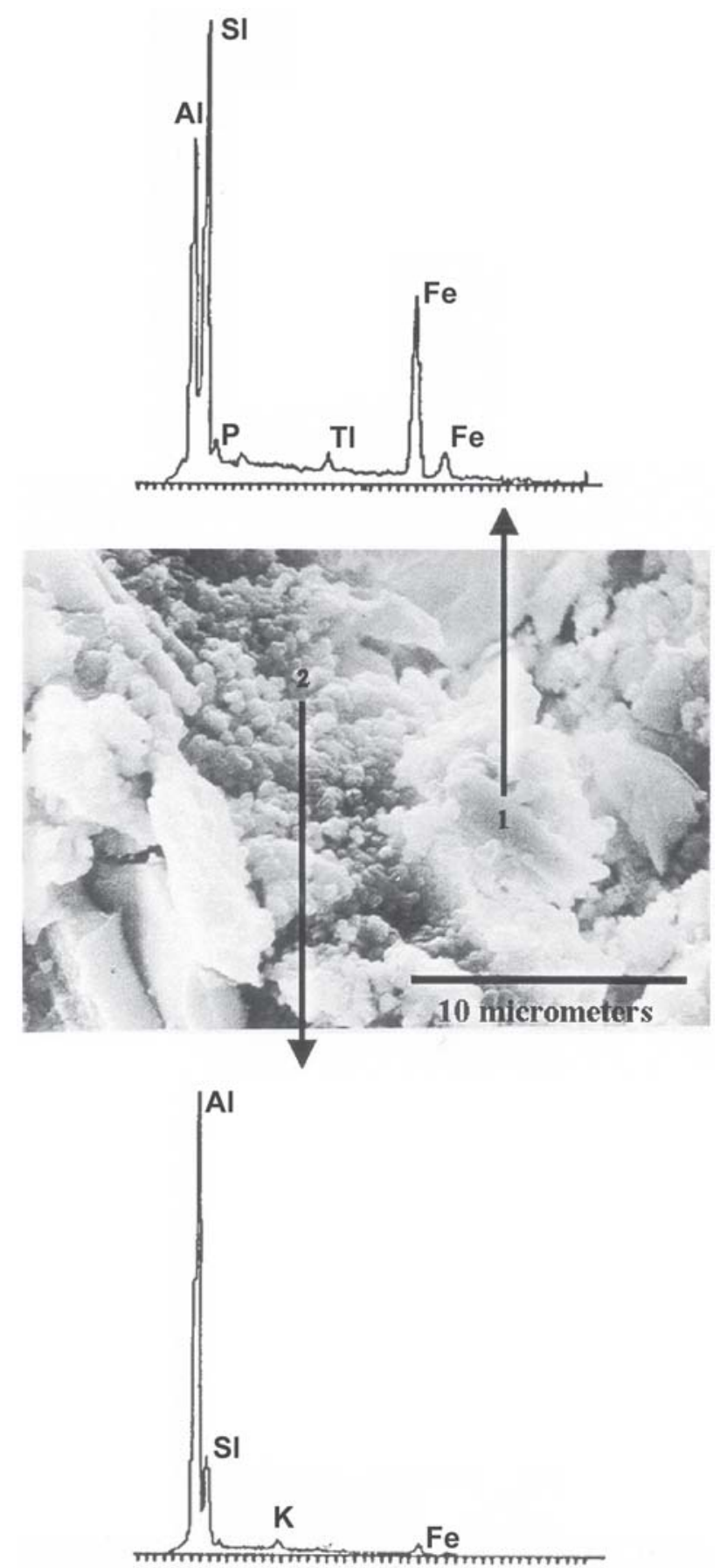

Figure 5 - Morphology and chemical composition at the core of a plagioclase septa.

About 85 to $90 \%$ of the rock volume was composed of a fine matrix which, according to Nardy et al. (1986), is mainly a microscopic intergrowth of quartz and alkaline feldspar, with spare crystals of plagioclase, pyroxene, Ti-magnetite, ilmenite, and small amount of an acicular apatite. Weathered matrix showed elongated subhedral crystals 8 micrometers long (Figure 7, A, spot 1) mixed with smaller hexagonal crystals 1 micrometer long (Figure 7, A, spot 2). Overall chemical analysis of this area showed mainly $\mathrm{Al}$ and Si. Subhedral crystals
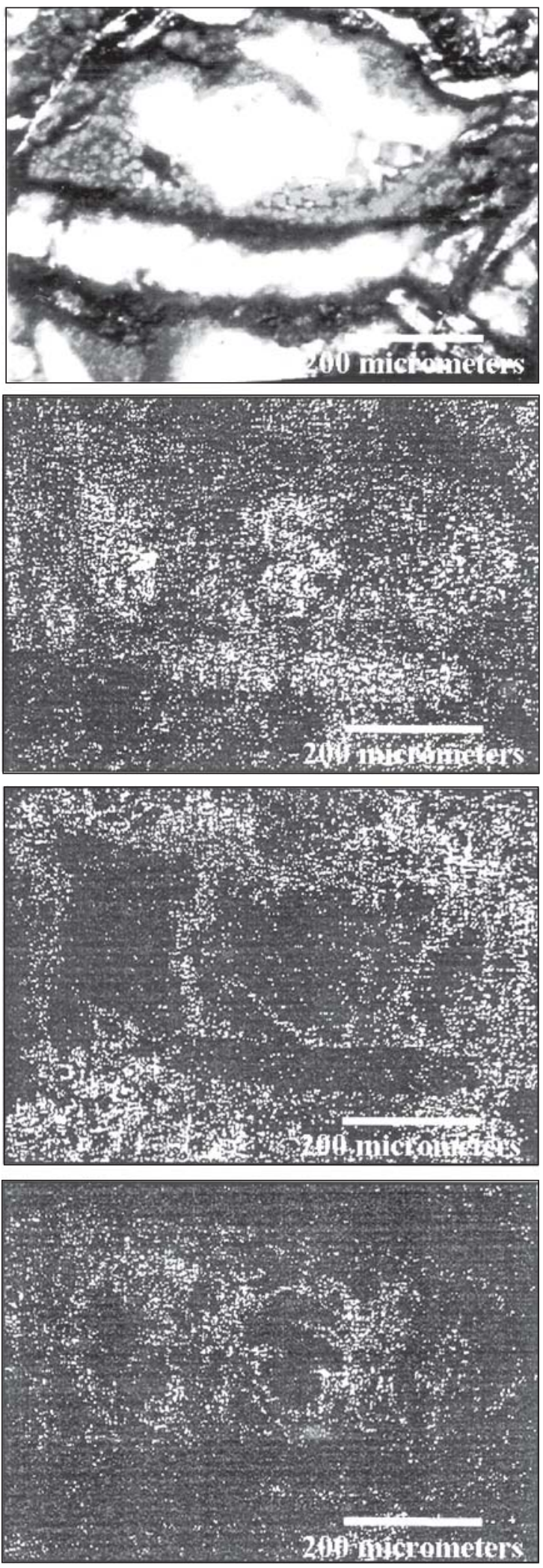

Figure 6 - Weathered pyroxen under the optical petrographic microscope (top) and elemental maps of $\mathrm{Al}, \mathrm{Si}$, and Fe.

were rich in $\mathrm{Al}$, suggesting gibbsite or amorphous $\mathrm{Al}$ hydroxide. The small hexagonal crystals had similar amounts of Si and $\mathrm{Al}$, suggesting kaolinite. 

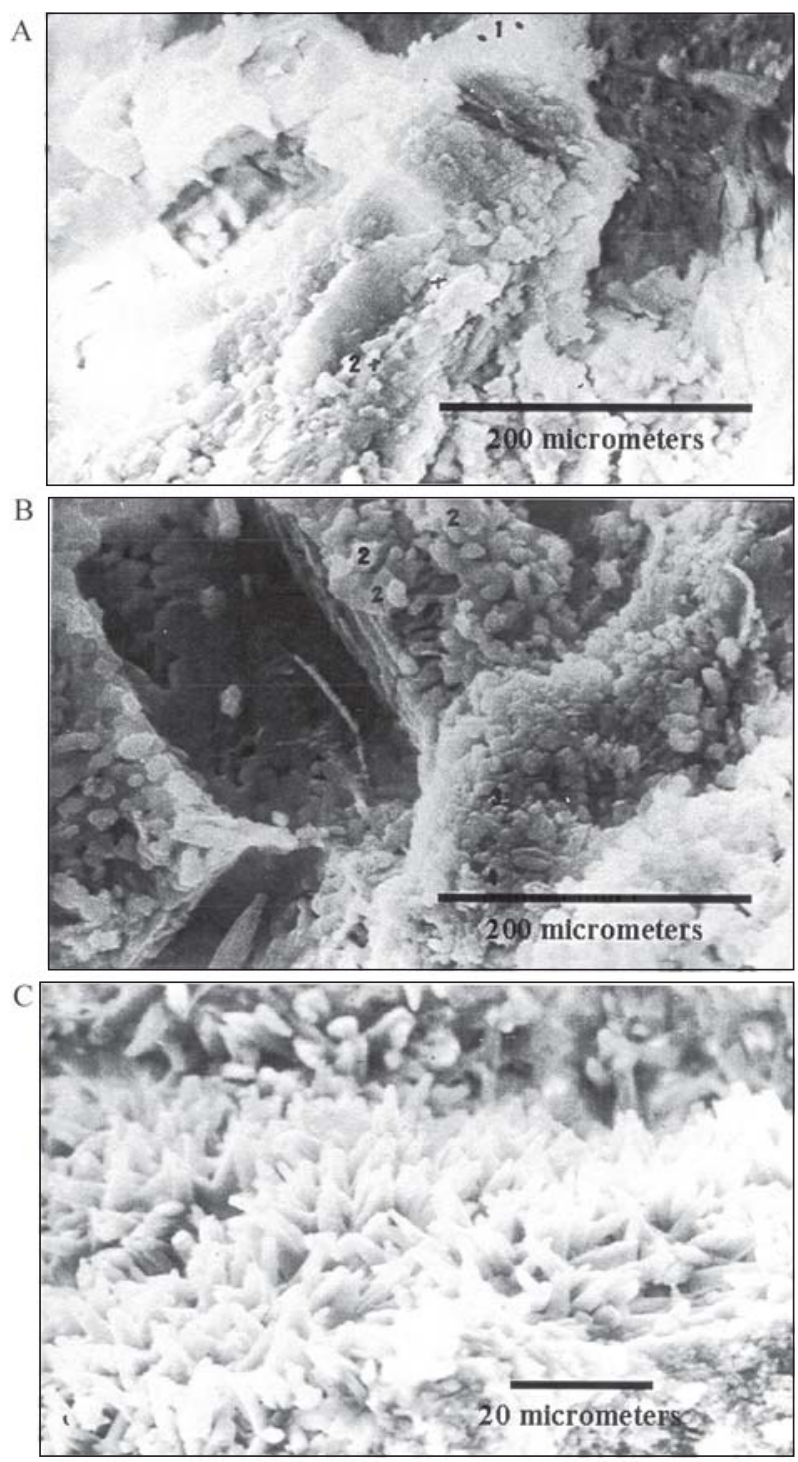

Figure 7 - Features of rock matrix weathering: A) large, elongated subhedral crystal (1) and small, hexagonal crystals (2); B) secondary quartz and C) probable gibbsite growth in fractures.

High Si concentration was found in voids that, as inferred by their morphology, should be previously occupied by primary minerals. Such products were mainly amorphous but, at some places, irregular prismatic crystals could be identified, suggesting secondary quartz about 2 micrometers long (Figure 7, B). Fractures in the rock matrix, about 0.5 to $1.0 \mathrm{~mm}$ wide, were filled by 5 micrometers acicular crystals composed mainly by $\mathrm{Al}$, suggesting presence of gibbsite (Figure 7, C).

Phyllosilicates (kaolinite) were an abundant weathering product in the rock matrix although scarce as a weathering product of phenocrystals (Table 1). In addition to the differences in chemical composition among phenocrystals and rock matrix, the porous network where water flows percolated played a key role in the weathering dynamics of these saprolites. According to White et al. (2001), if water flow is slow, weathering products maintain a high concentration and mineralogical phases can crystalize with less disturbance. In such conditions, solubility of feldspars dictates the weathering reactions: if the flow is high and the volume of percolating water is large the kinetics of the weathering reactions is the main driving factor. The dissolution of phenocrystals opened large pores to induce the flow of large and fast volume of percolating water, while such flow through the rock matrix was small and slow. Therefore Si activity should be higher in the rock matrix microenvironment than in the fissures allowing kaolinite to form. This hypothesis is suported by the weathering rate of pyroxenes, which is 3 to 13 orders of magnitude smaller than weathering rate of feldspars (Brantley \& Chen, 1995; Blum \& Stillings, 1995), but due to the small grain size (and therefore less acessibility for the percolationg water) could maintain Si activity high enough to form 2:1 phyllosilicates.

\section{CONCLUSION}

The most abundant weathering products of ATC riodacites from the high plateaus of Serra Geral Formation are kaolinite, gibbsite and iron oxides (goethite and hematite). The development of the saprolite porous network, including boxworks, and the weatherig products of primary minerals were influenced by the grain size of the minerals being dissolved. Dissolution of large crystals grains by weathering produced large pores, which allowed intense flows of water and, leaching of $\mathrm{Si}$, therefore weathering products were mainly oxides. Small crystal grains dissolution resulted in small pores, in which the Si activity in solution was high allowing the formation of phyllosilicates (mainly kaolinite).

\section{REFERENCES}

BLUM, A.E.; STILLINGS, L.L. Feldspar dissolution kinetics. In: WHITE, A.F.; BRANTLEY, S.L. (Ed.) Chemical weathering rates of silicate minerals. Washington, D. C.: Mineralogical Society of America, 1995. p.291-351.

BOULANGE, G. Les formations bauxitiques lateritiques de CôteD’ivoire. Mèmorie ORSTOM, v.175, p.363, 1984.

BRANTLEY, S.L.; CHEN, Y. Chemical weathering rates of pyroxenes and amphiboles. In: WHITE, A.F.; BRANTLEY, S.L. (Ed.) Chemical weathering rates of silicate minerals. Washington, D. C.: Mineralogical Society of America, 1995. p.119-172.

CERTINI, G.; WILSON, M.J.; HILLIER, S.J.; FRASER, A.R.; DELBOS, E. Mineral weathering in trachydacitic-derived soils and saprolites involving formation of embryonic halloysite and gibbsite at Mt. Amiata, Central Italy. Geoderma, v.133, p.173190, 2006. 
CHANDRAN, P.; RAY, S.K.; BHATTACHARYYA, T.; SRIVASTAVA, P.; KRISHNAN, P.; PAL, D.K. Lateritic soils of Kerala, India: their mineralogy, genesis, and taxonomy. Australian Journal of Soil Research, v.43, p.839-852, 2005.

CHOROVER, J.; AMISTADI, M.K.; CHADWICK, O.A. Surface charge evolution of mineral-organic complexes during pedogenesis in Hawaiian basalt. Geochimica et Cosmochimica Acta, v.68, p.4859-4876, 2004.

CLEMENTE, C.A. Alterações e solos desenvolvidos sobre rochas vulcanicas acidas da formação Serra Geral nos Planaltos de Guarapuava e Palmas, Região Centro-Sul do Estado do Paraná. Piracicaba: USP/ESALQ, 1988. 211p. Tese (Doutorado).

CORRÊA, J. Mineralogia e Gênese de solos de enconstas basalticas do Estado de Santa Catarina. Lages: UDESC, 2003. 103p. Dissertação (Mestrado).

DELVIGNE, J. Pèdogènese en zone tropicale: la formation des mineraux secondaires en milieu ferralitique. Mèmoire ORSTOM, v.13, p.177, 1965.

GARDNER, L.R. Long-term isovolumetric leaching of aluminum from rocks during weathering: implications for the genesis of saprolite. Catena, v.19, p.521-537, 1992.

HANRION, A.J. Techniques utilisées pour la preparation des lames minces petrographiques. Côte D'Ivoire: ORSTOM Centre D'Adiopodoume, 1976. 39p.

HSU, P.H. Aluminum hydroxides and oxyhydroxides. In: DIXON, J.B.; WEED, S.B. Minerals in soil environments. Madison: Soil Science Society of America, 1989. p.331-378.

HUANG, P.M. Feldspars, olivines, pyroxenes, and amphiboles. In: DIXON, J.B.; WEED, S.B. Minerals in soil environments. Madison: Soil Science Society of America, 1989. p.5-1050.

HUTCHINSON, G.E. The biosphere. San Francisco: W.H. Freeman, 1970. p.3-11.

MELFI, A.J.; PEDRO, G. Estudo geoquímico dos solos e formações superficiais do Brasil. Parte 1: Caracterização e repartição dos principais tipos de evolução geoquímica. Revista Brasileira de Geociências, v.7, p.271-287, 1977.

MELFI, A.J.; PEDRO, G. Estudo geoquímico dos solos e formações superficiais do Brasil. Parte 2: Considerações sobre os mecanismos geoquímicos envolvidos na alteração superficial e sua repartição no Brasil. Revista Brasileira de Geociências, v.8, p.11-23, 1978.
NAHON, D.B. Introduction to the petrology of soils and chemical weathering. New York: John Wiley, 1991. 313p.

NARDY, A.J. R.; MARQUES, L.S.; RAPOSO, M.I.B. Aspectos petrológicos das rochas efusivas ácidas da Região Centro Sul do Estado do Paraná. Revista Geociências, v.516, p.43-57, 1986.

PICIRILLO, E.M.; MELFI, A.J. The mesozoic flood volcanism of the Paraná Basin. São Paulo: USP-IAG, 1988. 600p.

ROISENBERG, A.; VIERO, A.P. O vulcanismo mesozóico da Bacia do Paraná no Rio Grande do Sul. In: HOLZ, M.; DE ROS, L. F. (Ed) Geologia do Rio Grande do Sul. Porto Alegre: Universidade Federal do Rio Grande do Sul, 2000. p.355-374.

SARTORI, R.L.P.; MACIEL FILHO, C.L.; MENEGOTTO, E. Contribuição ao estudo das rochas basálticas e seus produtos de alteração, Região de Santa Maria, RS. Porto Alegre: FAPERGS, 1973. 101p.

SCHIRRMEISTER, L.; STORR, M. The weathering of basaltic rocks in Burundi and Vietnam Catena, v.21, p.243-256, 1994.

SCHWERTMANN, U. The effect of pedogenic environment on iron oxide minerals. Advances in Soil Science. v.1, p.171200, 1985.

SCHWERTMANN, U.; TAYLOR, R.M. Iron Oxides. In: DXON, J.B.; WEED, S.B. Minerals in soil environments. Madison: Soil Science Society of America, 1989. p.9-438.

VELBEL, M.A. Mechanisms of saprolitization, isovolumetric weathering and pseudomorphous replacement during rock weathering: a review. In: INTERNATIONAL SYMPOSIUM OF GEOCHEMISTRY OF THE EARTH'S SURFACE AND MINERAL FORMATION, 2., Aix en Provence, 1990. Proceedings. p.17-18.

WHITE, A.F.; BULLEN, T.D.; SCHULZ, M.S.; BLUM, A.E.; HUNTINGTON, T.G.; PETERS, N.E. Differential rates of feldspar weathering in granitic regoliths. Geochimica et Cosmochimica Acta, v.65, p.847-869, 2001.

Received February 06, 2006

Accepted September 03, 2007 